\title{
Determination of Geotechnical Properties of Local Claystones in Northeast Koya City, Iraqi Kurdistan Region
}

\author{
Nawzat Rashad Ismail \\ Hemn Muhammad-Amin Omar \\ Dept. Geotechnical Engineering \\ Faculty of Engineering \\ Koya University
}

(Received 17/6/2019 , Accepted 28/11/2019)

\begin{abstract}
The aim of the current study is to determine the geotechnical properties of the investigated claystones /clayey soils in Koya area, Iraqi Kurdistan Region. This paper deals with the evaluating of the physical, mechanical and index properties of claystones. The study based on the field reconnaissance for twenty-five claystones samples were collected from five outcrops location within Fat'ha Formation. The results obtained from the laboratory tests revealed that the averages of specific gravity, porosity, void ratio, water absorption, natural water content and uniaxial compressive strength values of claystones are $(1.5,4.45 \%, 4.5,0.3,3 \%, 65 \mathrm{MPa})$ respectively. Whereas the results of the index geotechnical characterization of clayey soils revealed that the averages values of liquid limit, plastic limit, plastic index, flow index, toughness index, liquidity index, consistency index, swelling potential, activity index, and expansive potential are $(25.2,15.0,10.2,0.2$, $0.5,-1.2,2.2,0.62,0.31$, low or non-expansive) respectively. Among the index properties, the clayey soils are suitable for foundation and building materials industry. Furthermore, the regression coefficients of their correlation $\left(\mathrm{R}^{2}\right)$ obtained from the analysis show that there are strong relationships between the physical and mechanical properties of claystones. Concluding remark is that geotechnical properties of examined natural claystones satisfy the relevant regulation to be used for construction purposes.

Keywords: Claystone, Fat'ha Formation, Index Properties, Koya City, Water Absorption, Compressive Strength.






\begin{abstract}
الملخص
تهدف الدراسة الحالية إلى تحديد الخواص الجيوتقنية للتربة التي تم اختبارها والمتكونة من تربة الصلصال في منطقة كويا بإقليم كردستان العراق. تناول هذا البحث تقييم الخواص الفيزيائية والميكانيكية والدالة للحجر الطيني. استتدت الدراسة على أساس الاستطلاع الميداني لخمسة وعشرين عينة من الأحجار الصلصالية من خمسة مواقع المكاشف الصخرية لتكوين الفتحة. أوضحت النتائج التي تم الحصول عليها من الفحوصات المختبرية أن متوسط الوزن النوعي، المسامية، نسبة الفراغ ات امتصاص الماء، محتوى الماء الطبيعي وقيم مقاومة الضغط الأحادي للطين الصخري هي (1.5 ، 4.45 ، 4.5 ، 0.5 ، 3. ؛ ، 65 ميجا باسكال). على التوالي. في حين أظهرت نتائج التوصيف الجيوتقني لمؤشر التربة الطينية أن متوسطات قيم حد السيولة، حد اللدونة، معامل اللدونة، معامل التذفق، معامل الصلابة، معامل السيولة، معامل الاتساق، احتمالية الانتفاخ، مؤشر النشاط، والقدرة التوسعية هي (25.2 ، 15.0 ، 10.2 ، 0.2 ، 0.5 ، - 1.2 ، 2.2 ، 0.62 ، 0.31 ، منخفضة أو غير موسعة) على التوالي. من بين خصائص المؤشرة، تعتبر التربة الطينية مناسبة لصناعة الأساسات ومواد البناء. علاوة على ذلك، تظهر معاملات الانحدار لارتباطها (R²) التي تم الحصول عليها من التحليل أن هناك علاقات قوية بين الخواص الفيزيائية والميكانيكية للحجر الطيني. ملاحظة ختامية هي أن الخصائص الجيوتقنية للحجر الطيني الطبيعي الذي تم فحصه تفي بالتظيم ذي الصلة ليتم استخدامه لأغراض البناء.

الكلمات الدالة: الحجر الطيني، تكوين الفتحة، الخصائص الدالة، مدينة كويا، امتصاص الماء، قوة الضغط.
\end{abstract}

\title{
INTRODUCTION
}

Geotechnical properties and behavior of the rocks such as calystones are important due to their importance as constructing materials to develop countries (Maala et al., 2001). These materials have great economic value as main raw materials for the construction, crushed rock aggregate, glass, chemical, and ceramics industries (Amavilah, 1995). Claystones have been considered as part of many architectural heritages and their look and characteristics depending on their source material, transport processes and mineralogical composition as well as the depositional environment (Cultrone et al., 2012). Therefore; it is necessary to acquire detailed information on sedimentological, mechanical and physical parameters of sedimentary rocks to predict their properties during construction (Morales, et al., 2007). There are many researchers deal with the assessment of geotechnical properties of claystones and clayey soils in Iraq, but there are no study deals with prediction of these properties to be used as raw materials for construction and building purposes in Koya City. Merza (2004) used the recent deposits of salty clay around the Aliawa Village, in the south of Sulaimania city for production of glazed ceramic tiles through mixing recent deposits of Sirwan River deposits. Khalid (2012) worked on the geotechnical assessment of soil from selected sites in Tikrit City, central Iraq, the result indicates weak geotechnical properties, because it is mostly gypsum soil with friable sandy content. Rasheed et al. 
(2016) indicated that the clayey soils recognized within the tested area have poor clay activity, so these soils have a low swelling tendency and there is a wide variety in the permeability of soils according to the wide variety in soils types and formations.

Basically, this research focuses on raw materials of claystone aiming to assess the geotechnical properties and behavior of this rock. To support this current study, we added the clayey soil study because of the high prevalence and thickness of these rocks in large area. The study area refers to Fat'ha Formation that is one of the most widespread and economically has an important value in Iraqi Kurdistan region. The Fat'ha Formation consists mainly of pale reddish-brown clay with light gray marlstone and white color of gypsum, well and moderately bedded claystone interbedded within layers of marlstone (Jassim, et al, 2015). Based on the field reconnaissance, twenty five claystone and three soil samples are collected from five locations within Fat'ha Formation.

\section{Field Work:}

\section{MATERIALS AND METHODS}

The locations of the study samples are bounded by UTM grid 3994129 and 3995398 North, 0468384 and 0469604 East, as shown in (Table 1 and Figure 1).

The procedure is following the national and international methods such as (ISRM, 1985), (NZGS, 2005), (Cassagrande, 1932), (ASTM, 1996), (USCS, 1953), (Iraqi Standard, 1989).

\begin{tabular}{|ccc}
\hline $\begin{array}{c}\text { Table 1: Locations of outcrops samples in the study area by Universal Transverse Mercator } \\
\text { (UTM). }\end{array}$ \\
\hline \hline Location no. & Formation & $\begin{array}{c}\text { Coordinates } \\
\text { (North and East line) }\end{array}$ \\
\hline 1 & Fat'ha & $3994980 \mathrm{~N}$ and 0468994 E \\
2 & Fat'ha & $3995129 \mathrm{~N}$ and 0468837 E \\
3 & Fat'ha & $3995398 \mathrm{~N}$ and 0468384 E \\
4 & Fat'ha & $3994129 \mathrm{~N}$ and 0469144 E \\
5 & Fat'ha & 3994387 N and 0469604 E \\
\hline \hline
\end{tabular}




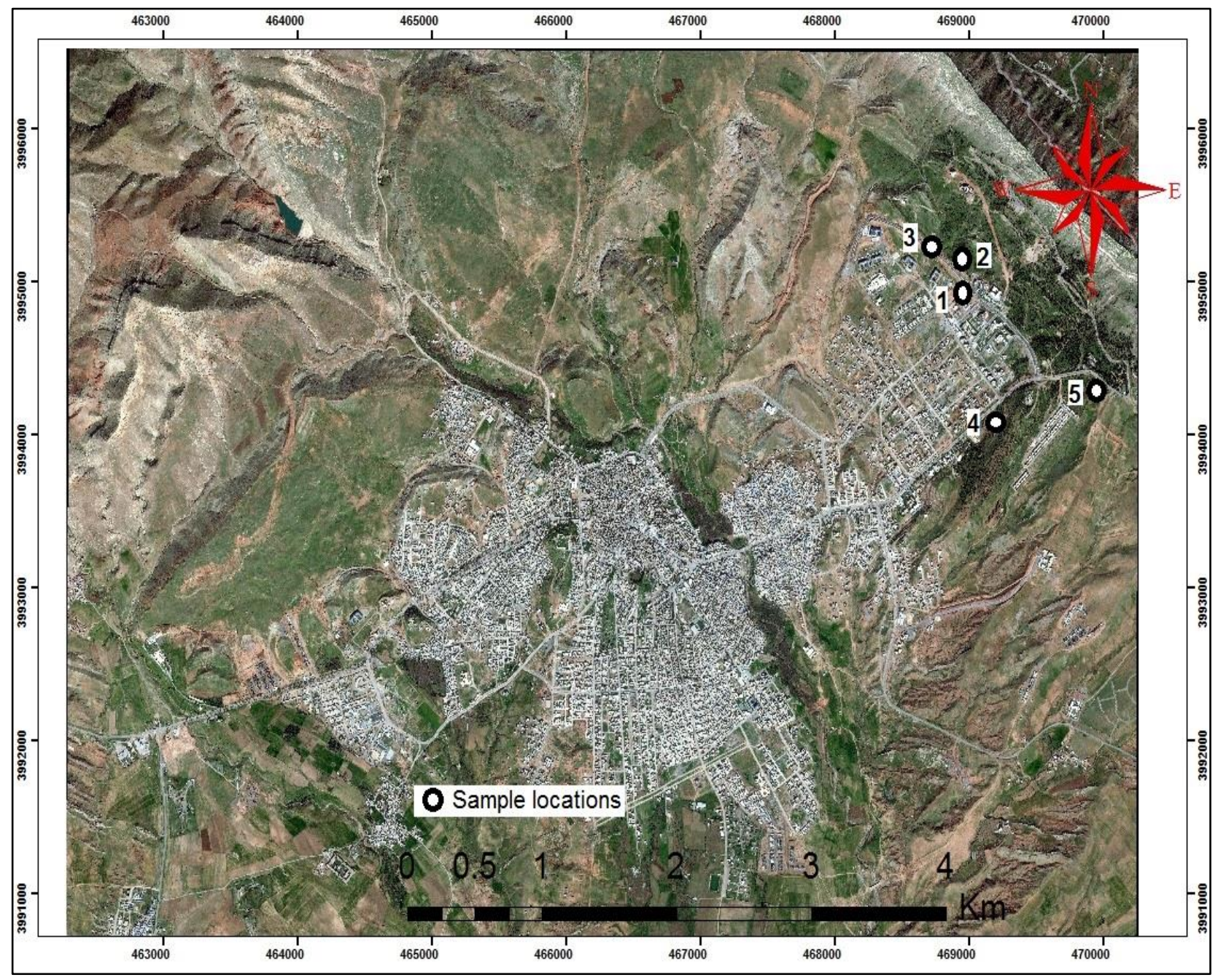

Fig. 1: Satellite image of Koya City indicates the sample locations.

\section{DETERMINATION OF GEOTECHNICAL PROPERTIES}

In order to determine the geotechnical properties of claystones specimens, index tests were performed in the laboratory, as follows: porosity (n), specific gravity, void ratio, water content and water absorption, compressive strength (Tables 2;3). 


\begin{tabular}{|c|c|c|c|c|c|c|c|c|c|}
\hline $\begin{array}{l}\text { Locati } \\
\text { on } \\
\text { No. }\end{array}$ & $\begin{array}{l}\text { Sampl } \\
\text { e No. }\end{array}$ & $\begin{array}{c}\text { Dry } \\
\text { Weight } \\
\text { (g) }\end{array}$ & $\begin{array}{c}\text { Weight of } \\
\text { Stone } \\
\text { (after } 24 \\
\text { hrs in } \\
\text { Water) (g) }\end{array}$ & $\begin{array}{c}\text { Weight } \\
\text { in water } \\
(\mathrm{g})\end{array}$ & $\begin{array}{c}\text { Water } \\
\text { Conte } \\
\text { nt } \\
(\%) \\
\end{array}$ & $\begin{array}{c}\text { Water } \\
\text { Absorptio } \\
\mathrm{n} \\
(\mathrm{W} \%) \\
\end{array}$ & $\begin{array}{l}\text { Specific } \\
\text { Gravity }\end{array}$ & $\begin{array}{l}\text { Porosity } \\
(\%)\end{array}$ & $\begin{array}{l}\text { Void } \\
\text { Ratio }\end{array}$ \\
\hline \multirow{6}{*}{ L1 } & S1 & 1175.2 & 1227.5 & 437.6 & 4.45 & 0.045 & 1.48 & 6.2 & 6.6 \\
\hline & S2 & 1476.6 & 1527.9 & 542.1 & 3.47 & 0.034 & 1.49 & 4.94 & 5.2 \\
\hline & S3 & 1034.8 & 1068.35 & 338.1 & 3.24 & 0.032 & 1.41 & 4.4 & 4.59 \\
\hline & S4 & 462.3 & 484.1 & 189.1 & 4.5 & 0.045 & 1.56 & 6.88 & 7.38 \\
\hline & S5 & 1064.1 & 1105.6 & 400.8 & 3.9 & 0.039 & 1.51 & 5.56 & 5.88 \\
\hline & Average & & & & 3.9 & 0.039 & 1.49 & 5.596 & 5.93 \\
\hline \multirow{6}{*}{$\mathrm{L} 2$} & $\mathrm{~S} 1$ & 586.2 & 602.05 & 341 & 2.7 & 0.027 & 2.24 & 5.72 & 6.06 \\
\hline & S2 & 1130.4 & 1159.5 & 408.5 & 2.57 & 0.025 & 1.50 & 3.73 & 3.87 \\
\hline & S3 & 878.3 & 894.75 & 292.6 & 1.87 & 0.018 & 1.46 & 3.12 & 3.23 \\
\hline & S4 & 339.4 & 353.05 & 161.3 & 4.02 & 0.0402 & 1.77 & 6.6 & 7.11 \\
\hline & S5 & 1304.8 & 1347.15 & 539.2 & 3.25 & 0.032 & 1.61 & 4.98 & 5.24 \\
\hline & Average & & & & 2.88 & 0.0284 & 1.716 & 4.83 & 5.102 \\
\hline \multirow{6}{*}{ L3 } & S1 & 846.2 & 869.5 & 209.4 & 2.75 & 0.027 & 1.28 & 3.4 & 3.5 \\
\hline & S2 & 1049.75 & 1079.6 & 467.1 & 2.84 & 0.028 & 1.71 & 4.6 & 4.87 \\
\hline & S3 & 1055.85 & 1092.4 & 399.8 & 3.46 & 0.034 & 1.52 & 5.0 & 5.27 \\
\hline & S4 & 1600.1 & 1633.85 & 687.7 & 2.11 & 0.021 & 1.69 & 3.44 & 3.56 \\
\hline & S5 & 1005.65 & 1038.5 & 260.9 & 3.27 & 0.032 & 1.29 & 4.05 & 4.22 \\
\hline & Average & & & & 2.886 & 0.0284 & 1.498 & 4.098 & 4.284 \\
\hline \multirow{6}{*}{$\mathrm{L} 4$} & S1 & 1479.3 & 1509.1 & 613.7 & 2.01 & 0.020 & 1.65 & 3.22 & 3.32 \\
\hline & S2 & 2440 & 2488.9 & 858.6 & 2 & 0.020 & 1.49 & 2.91 & 2.99 \\
\hline & S3 & 2661.4 & 2731.6 & 860.7 & 2.64 & 0.026 & 1.42 & 3.61 & 3.75 \\
\hline & S4 & 1253.8 & 1268 & 474.1 & 1.13 & 0.011 & 1.58 & 1.75 & 1.78 \\
\hline & S5 & 1908.6 & 1947.9 & 495.4 & 2.05 & 0.020 & 1.31 & 2.63 & 2.7 \\
\hline & Average & & & & 1.966 & 0.0194 & 1.49 & 2.824 & 2.908 \\
\hline \multirow{6}{*}{ L5 } & S1 & 2071.5 & 2130.55 & 688.4 & 2.85 & 0.028 & 1.44 & 3.93 & 4.09 \\
\hline & S2 & 2037.45 & 2092.70 & 572.1 & 2.7 & 0.027 & 1.33 & 3.5 & 3.6 \\
\hline & S3 & 2176.7 & 2267.4 & 528.5 & 4.2 & 0.042 & 1.25 & 4.95 & 5.2 \\
\hline & S4 & 939.9 & 982.4 & 317.9 & 4.5 & 0.045 & 1.41 & 6.01 & 6.39 \\
\hline & S5 & 2230.7 & 2325.3 & 918 & 4.24 & 0.042 & 1.58 & 6.29 & 6.7 \\
\hline & Average & & & & 3.698 & 0.0368 & 1.402 & 4.936 & 5.196 \\
\hline
\end{tabular}




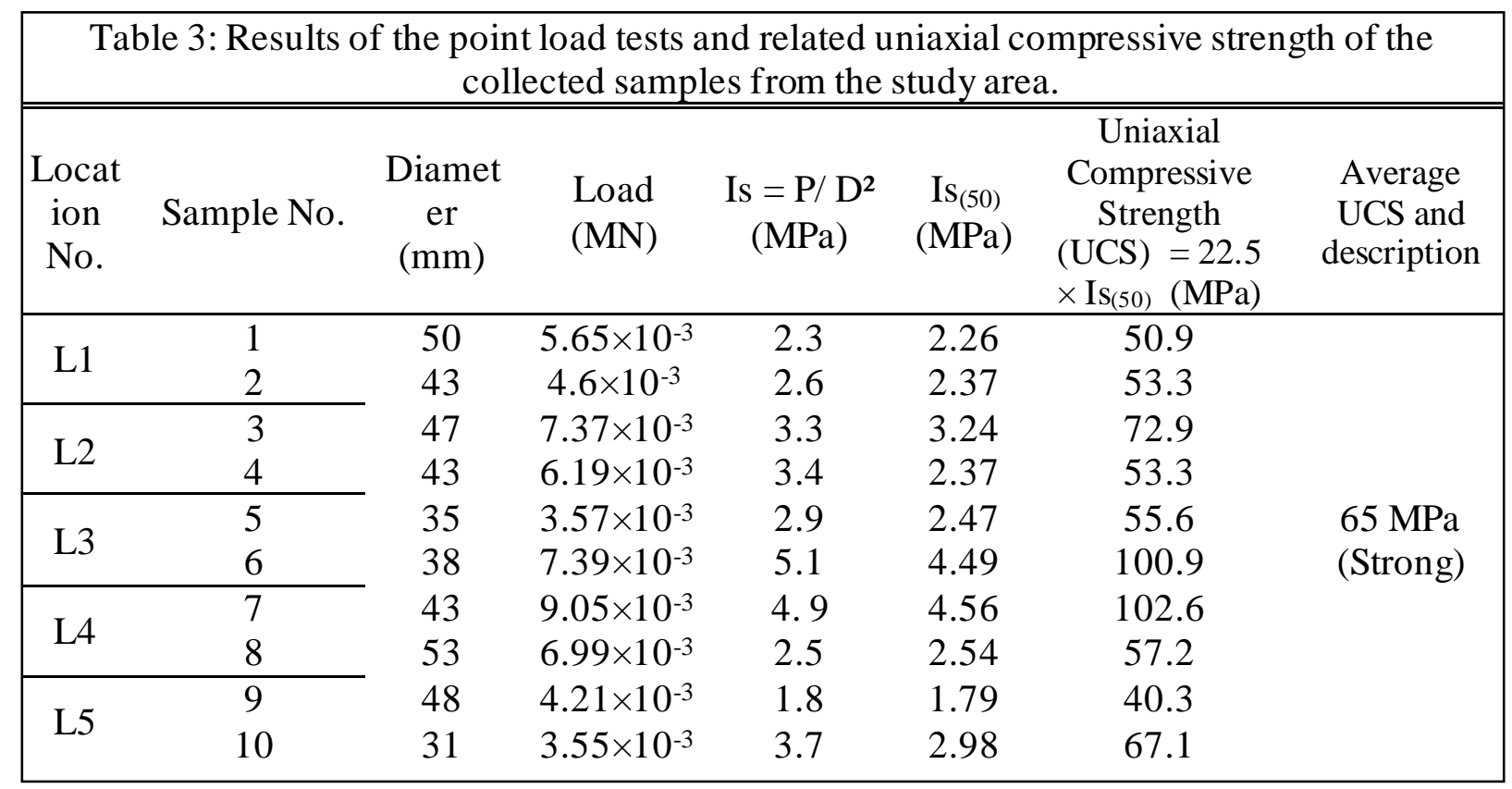

Three samples of clayey soils collected from the same location of claystone samples are used for the present investigation. The following geotechnical tests were carried out as indices like: liquid limit (LL), plastic limit (PL), plasticity index (PI), flow Index $\left(\mathrm{I}_{\mathrm{f}}\right)$, toughness Index $\left(\mathrm{I}_{\mathrm{t}}\right)$, liquidity index $\left(\mathrm{I}_{1}\right)$, consistency index $\left(\mathrm{I}_{\mathrm{c}}\right)$, swelling potential $(\mathrm{S})$, activity $\left(\mathrm{A}_{\mathrm{c}}\right)$, and expansive potential (EP), (Tables 4; 5). The most determined index properties of clayey soil samples are shown in (Table 6).

\begin{tabular}{|ccccc|}
\hline \multicolumn{5}{|c|}{ Table 4: The results of Atterberge limits and the corresponding type of clayey soil } \\
samples.
\end{tabular}

\begin{tabular}{|cccc|}
\hline \multicolumn{4}{c|}{ Table 5: The particle size distribution percentage of the studied samples. } \\
\hline \hline \multirow{4}{*}{ The Particle Size Distribution \% } \\
\hline \multirow{2}{*}{ Sample Symbol } & Clay \%, < & Silt \%, 0.002- & Sand \%, 0.063 \\
& $0.002 \mathrm{~mm}$ & 0.063 & -2.0 \\
\hline S1 & 40 & 59 & 1 \\
S2 & 31 & 48 & 21 \\
S3 & 30 & 66 & 4 \\
\hline
\end{tabular}




\begin{tabular}{|ccccccc|}
\hline \multicolumn{6}{|c|}{ Table 6: The results of some indices properties of studied clayey soil samples. } \\
\hline \hline $\begin{array}{c}\text { Sampl } \\
\text { e No. }\end{array}$ & $\mathrm{I}_{\mathrm{f}}$ & $\mathrm{I}_{\mathrm{t}}$ & $\mathrm{I}_{\mathrm{l}}$ & $\mathrm{I}_{\mathrm{c}}$ & $\mathrm{S}$ & $\mathrm{A}_{\mathrm{c}}$ \\
\hline S1 & 0.18 & 0.55 & -1.0 & 2.0 & 0.59 & 0.25 \\
S2 & 0.25 & 0.40 & -1.2 & 2.2 & 0.59 & 0.33 \\
S3 & 0.19 & 0.55 & -1.3 & 2.3 & 0.67 & 0.35 \\
Average & 0.20 & 0.50 & -1.2 & 2.2 & 0.62 & 0.31 \\
\hline
\end{tabular}

\begin{tabular}{|ccccccc|}
\hline \multicolumn{7}{|c|}{ Table 7: Degree of Expansive Potential (EP) in Term of PI, LL, and S of clayey soil samples in } \\
present study.
\end{tabular}

\section{RELATIONSHIPS BETWEEN ATTERBERG LIMITS, SWELLING POTENTIAL AND EXPANSIVENESS OF CLAYEY SOILS}

To understand the engineering expansive soils in an effective way, it is necessary to understand soil properties. Expansive soils are one of the most significant ground-related hazards found globally, contributing billions of pounds annually (Jones and Jefferson, 2012).

Expansive soils are found throughout the world and are commonly found in arid/semiarid regions where their high suctions and potential for large water content changes on exposure/ deficient with water can cause significant volume changes. Nelson and Miller (1992) deduced that there is the linear relationship between Atterberg limits and expansive characteristics of clayey soils. Expansive clays are identified by mineralogy, direct measurement of swelling characteristic, and by indirect correlation of swelling characteristic with simple index properties such as plasticity index (Altmeyer, 1988). Liquid limit (LL), plasticity index (PI) and swelling potential (S) were analyzed to recognize directly the degree of expansive potential $\left(\mathrm{E}_{\mathrm{P}}\right)$ depending on some previous studies as shown in (Table 7). 


\section{CORRELATIONS BETWEEN INTACT ROCK PROPERTIES}

The dependence of the compressive mechanical properties on the physical properties of rocks has been reported by several authors (Du et al, 2013). Regression analyses were also applied to define the relations among the obtained parameters. The procedure is to fit a line through the points, which is computed so that the squared deviations of the measured points from the line are minimized. The line is defined by the relevant equation, whereas the value of the coefficient of determination or R-square value is determined. The number of samples used for regression analyses is also shown. Figures $(2-4)$ depict the graphical representations of the relationship between the parameters.

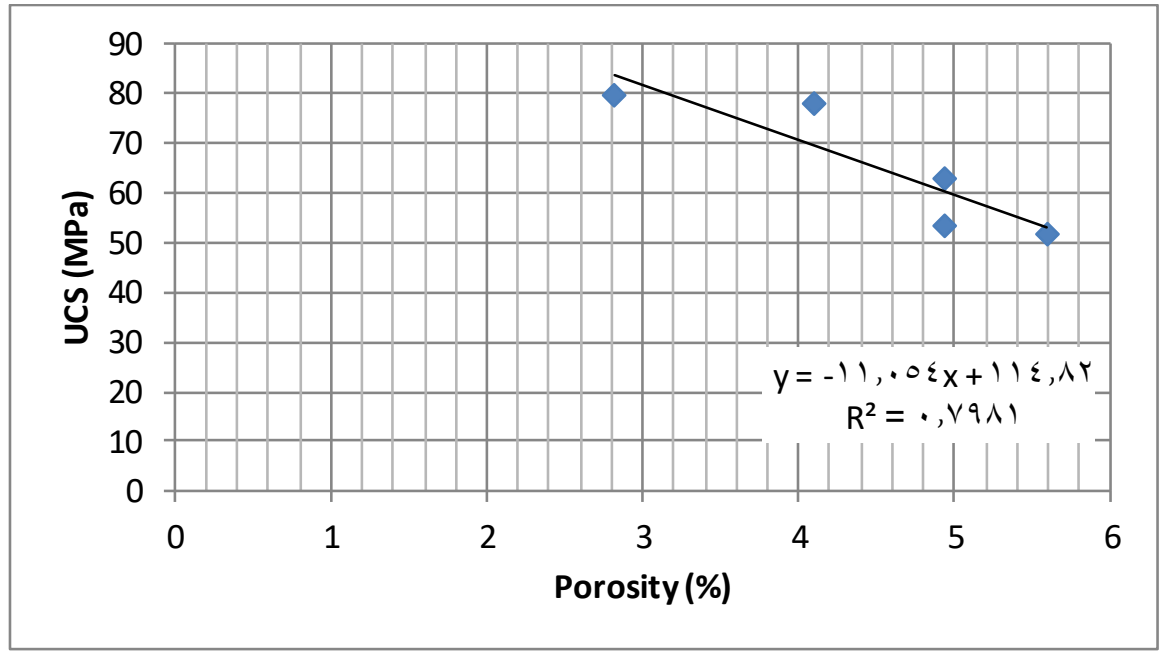

Fig. 2: Correlation between uniaxial compressive strength and porosity .

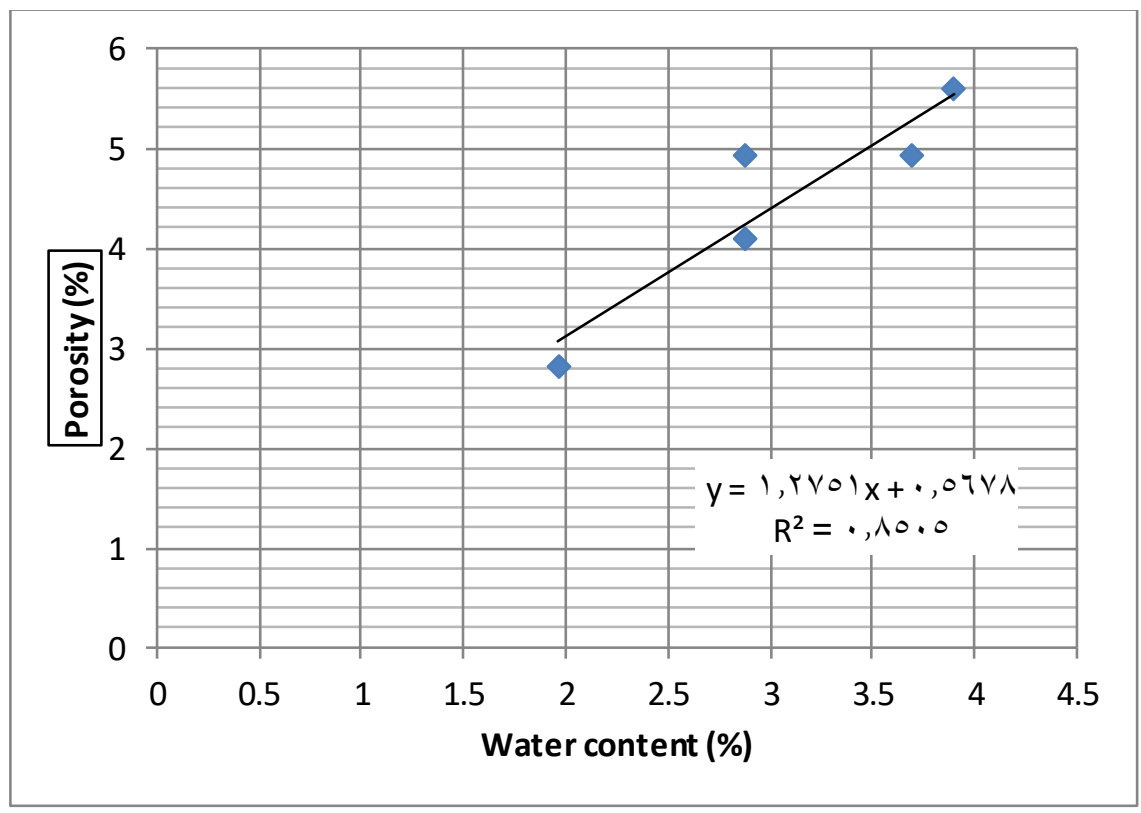

Fig. 3: Correlation between porosity water content. 


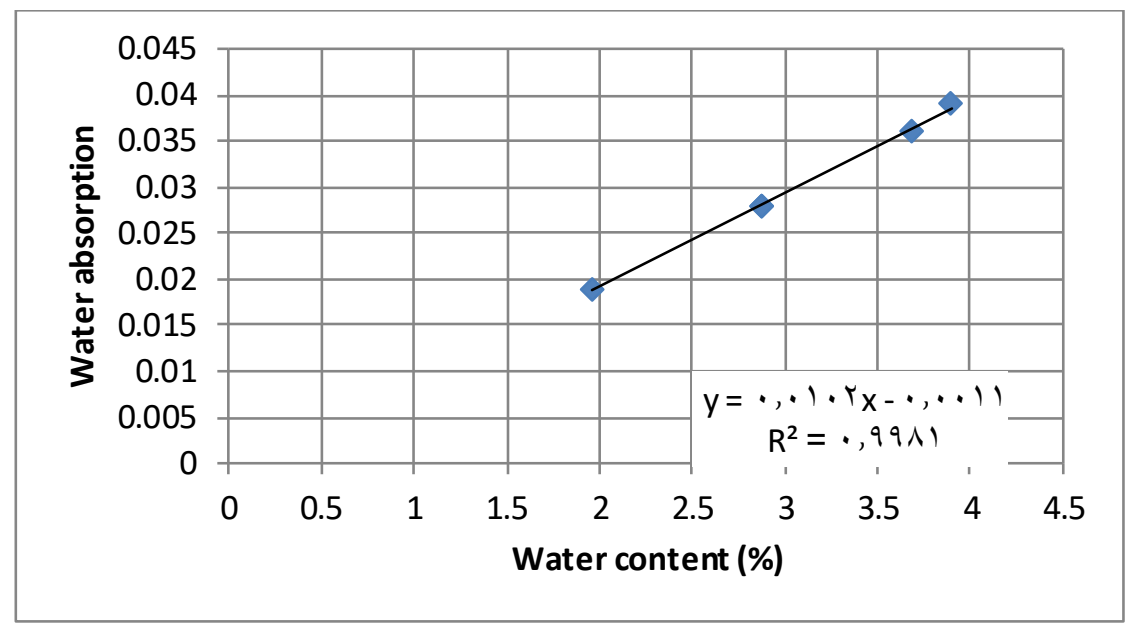

Fig. 4: Correlation between water absorption and water content.

\section{RESULTS AND DISCUTION}

There are many properties for stabilizing claystones to gain required engineering specification of construction materials. The geotechnical properties of claystones are highly influenced by the clay particles content. The results from our laboratory investigations show that the claystones from the Fat'ha Formation have minor differences in their geotechnical properties. These differences result from their different diagenesis (causing varying pore space, water content and strength properties). The test results are summarized in (Tables 2, $3,4,5$, and 7).

Specific gravity is influenced primarily by the density of the minerals, their content inside the rock (Bell and Lindsay 1999). In the investigated samples of Fat'ha Formation, the specific gravity displayed little variation and range from 1.4 to 1.7 , with a mean value of 1.5 for claystone. All of the tested samples had a moderate specific gravity according to Iraqi Standards (1989). The values of the absolute porosity varied from $4.09 \%$ to $5.59 \%$ with a mean value of $4.45 \%$ and the void ratio range from 2.9 to 5.93 with an average value of 4.6 for claystone. According to the mean value, these rocks generally have a low porosity and void ratio. The obtained values of water absorption from 0.019 to 0.039 with an average value of 0.3 indicate very low water absorption. All the investigated samples were resistance to frost. The mass loss after freezing and thawing was low due to the low porosity of the rocks.

The result of water content ranges from $1.96 \%$ to $3.9 \%$ with an average value of $3 \%$. This shows that the samples have a low effective porosity (Khanal and Tamrakar, 2009). Hence, and according to the concepts of scientific research, it is very necessary to invest this layer of claystone as raw material for the construction and industry materials. Moreover, this layer is characterized by the attributes of encouraging quarrying.

Among the most important parameters controlling the weathering behavior of stones are strength properties, such as tensile strength and compressive strength. This is because the stresses induced by mechanical weathering processes have to exceed the strength of a material for failure to occur. Thus, these parameters can be considered a measure for the grain fabric cohesion (Graue et al., 2011). As shown in (Table 3), the results obtained from 
the mechanical analyses claystones, samples are very suitable for construction purposes because of their good strength properties with a mean value of $65 \mathrm{MPa}$ as well as their low porosity. According to the suggested method by New Zealand Geotechnical Society (2005), these rocks are classified as strong rocks and this value has inversely proportional relation with the lower water absorption (Naghoj et al., 2010).

Atterberg limits of clayey soils are very important in construction materials. Prior to construction works expansive soils have to be stabilized to provide adequate support for roads, foundations, and buildings. From the results of Atterberg limits and indices properties, the average of plasticity index value $(10.2 \%)$, that means the studied samples belong to medium plasticity inorganic clayey in nature (CL), according to Standards American Society for Testing and Materials (1996) and Casagrande plasticity chart (Casagrande, 1932). Hence these soils do not have organic matter (Table 4). Based on the plasticity values pointed out that this percentage is less proportional with the clay minerals water content such as (kaolinite, illite, chlorite), because molecular nature of these clay minerals have not ability to drawn the water (i.e., they do not absorb water, does not expand where they are contact with water) whereas montmorillonite derived by weathering of volcanic ash, it can expand by several times its original volume when it comes in contact with water (Klein, 2002). The average value of flow index $\left(\mathrm{I}_{\mathrm{f}}\right)=0.2$, so the flow index of clayey soils has higher shear strength as a function of low water content. The average value of toughness index $\left(\mathrm{I}_{\mathrm{t}}\right)$ is $(0.5)$, hence this soil with toughness index $<1$ is called friable soil or medium stiffness which means that it is required medium pressure to roll the thread to near plastic limits. While the average value of liquidity index $\left(\mathrm{I}_{1}\right)$ and consistency index $\left(\mathrm{I}_{\mathrm{c}}\right)$ is $(-1.2,2.2)$ respectively, it indicates that the type of clayey soils classified to stiff or semisolid state consistency due to the $\mathrm{I}_{\mathrm{c}}>1, \mathrm{I}_{1}$ has a negative value according to German Standard Classification (DIN, 2008) (Table 6), as a result it is suitable for foundation design. The average value of $\left(\mathrm{A}_{\mathrm{c}}\right)=0.31$, that means the original kaolinite clay mineral represents the highest percentage of clayey soil $>50 \%$ content, and the class of clayey soil is inactive clays due to the value of activity $<0.75$ (Skempton, 1953; Nelson and Miller, 1992). The clayey soil samples have variation in swelling potential with respect to plasticity index and activity of around $(0.62,10.2$, and 0.31$)$ respectively, showing that there is a direct relationship between them. It may be noted that the swelling potential for volume change is low with inactivity clayey soil (Tables 5 and 6). A successful design and construction of foundation on expansive soils requires a good understanding of swelling characteristic, relationships between expansive potential $\left(\mathrm{E}_{\mathrm{P}}\right)$ and index parameters show that the expansive characteristics will very similarly with respect to PI, LL and S. Table (7) summarizes the degree of expansive potential in terms of these indices of simple descriptive ratings. These ratings are derived from the literature or from the empirical data, indicating that decreasing (low or non-expansive) in the effects of the degree of expansive on the clayey soils samples associated with decreasing of water content, void ratio, and the type of clay minerals in the soil (Krenz et al., 2006). This result agrees with Cimen et al. (2012) who stated that plasticity characteristics and volume change behavior of soils are related to the number of clay particles in the soil and that swelling property of clay minerals are directly proportional to their plasticity properties. 


\section{Regression Analysis:}

Statistical models were generated to relate the mechanical properties to the physical properties. The results of models revealed that as the uniaxial compressive strength of claystones increases and porosity decreases. The linear and power function relationships seem to fit the data better, the good fit of the power regression between these parameters is expressed by equation $y=-11.054 x+114.82$ with $\left(\mathrm{R}^{2}=0.798\right)$, as shown in (Figure 2$)$.

As shown in (Figure 3) the trend relating porosity and water content is an approximately linear function which is expressed by equation $y=1.275 \mathrm{x}+0.5678$ with $\left(\mathrm{R}^{2}\right.$ $=0.85$ ), porosity increases with increasing water content. The results of the relationships revealed high correlation coefficient between water content values and water absorption indicating that water content is strongly related to water absorption value, the best fitting curve between these parameters is expressed by equation $\mathrm{y}=0.0102 \mathrm{x}-0.0011$ with $\left(\mathrm{R}^{2}=\right.$ 0.998), as shown in (Figure 4). Other authors Türkdönmez and Bozcu, 2012; Karaman et al. (2006) have also proposed quite similar linear type relationships between these parameters of intact rock for various types of rocks. Generally, all the tested rock samples have a moderate specific gravity, low porosity and void ratio, very low water absorption and natural water content with strong compressive strength show that the physical and mechanical properties pointed out that the clay stones are suitable for many civil engineering structure projects such as construction and cementing materials, road materials according to national and international standard specification, which is mentioned in the current study. On the other hand, the values of index properties of clayey soil such as Attemberg limits, flow index, toughness index, liquidity index, etc indicated that it is suitable to support the roads, foundations and building materials due to the expensive value of fundamental characteristics of this clayey soil based on international standard specification.

\section{CONCLUSIONS}

The following conclusions can be drawn from this research:

1) The Fat'ha Formation in the study area consists mainly of pale reddish-brown clay, light gray marlstone with white color of gypsum and regularly bedded rock masses of claystone.

2) The physico-mechanical properties of claystone within different locations pointed out that the investigated claystone has the strong compressive strength. All of the tested samples had a moderate specific gravity, generally have a low porosity, void ratio, very low water absorption and water content. They show slightly weathering processes with cracks or fractures.

3) The Atterberg limits are found to be almost linear with respect to the clay content. Liquid limit with plasticity index defines information about the types of clay, classification of the grained clayey soil can be obtained from plasticity chart, which could be attributed to medium plasticity inorganic clayey nature (CL), which permits them to be shaped or molded when mixed with water. 
4) The values of flow, toughness, liquidity and consistency indices refer to that clayey soil has higher shear strength, medium stiffness, and semisolid state consistency classification.

5) The rate of reduction of the expansive potential (low or non-expansive) and inactivity class of clayey soils results associated with kaolinite clay mineral $>50 \%$ content generally applied to prevent the ability of a clayey soil to undergo large changes in volume due to the decrease in moisture content.

6) Good positive relationships between Atterberg limits, swelling potential, and expansiveness of clayey soils deduced that there is a linear relationship between them. This result agrees with (Elkholy, 2008), who stated that the solution to the problem of foundations on expansive soils cannot be achieved without an understanding of the fundamental characteristics of expansive soils and the variables involved that affect the swelling phenomena and consistency limits of soils.

7) The coefficients of the correlations $\left(\mathrm{R}^{2}\right)$ indicate a strong relationship between the physical and mechanical properties of claystones by positive linear relationship exists between them.

8) The low thickness of the overburden has significant economic benefits making the reserve quarry ability very easy and then eventually reducing the final cost of construction materials.

Therefore, it can be concluded that the overall characteristics of claystones and clayey soils results show sufficient quality, can be verified and mainly used as the basic raw material of architecture and construction industries such as interior and exterior uses (decorative aggregates, floor and roof tiles, building, facing and paving stones).

\section{EFERENCES}

Altmeyer, W. T. (1988). Discussion of engineering properties of expansive clays. Proceedings of American Society of Civil Engineers, 81, separate No.658.

Amavilah, V. H. S. (1995). Industrialization, Mineral Resources and Energy in Africa edited by Smail

Khennas - Reviews. Journal of Modern African Studies, 33 (3), 503-506.

ASTM, American Society for Testing and Materials, (1996). D4318: 1996 Standard test method for liquid limits, plasticity index of soils. America: ASTM.

Bell, F. G. \& Lindsay, P. (1999). The petrographic and geomechanical properties of some sandstones from the Newspaper Member of the Natal Group near Durban. Engineering Geology, 53, 57-81.

Casagrande, A. (1932). Research on the atterberg limits of soils. Public Roads, 13(8), 121136.

Cimen, O., Keskin SN. \& Yildirim H. (2012). Prediction of Swelling Potential and Pressure in Compacted Clay. Arabian Journal of Science and Engineering, 37(6), 1535-1546.

Cultrone, G., Luque, A., \& Sebastián, E. (2012). Petrophysical and durability tests on sedimentary stones to evaluate their quality as building materials. Quarterly journal of engineering geology and hydrogeology, 45, 415-422. 
DIN. (2008). 18122-1: 2008. Erkundung und Untersuchung des Baugrunds, Beuth Verlag, Berlin, Germany.

Du, Y., Wei, M., Jin, F., and Liu Z. (2013) Stress-strain relation and strength characteristics of cement treated zinc-contaminated clay. Engineering Geology, 167, 20-26.

Graue, B., Siegesmund, S., \& Middendorf, B. (2011). Quality assessment of replacement stones for the Cologne Cathedral: mineralogical and petrophysical requirements. Environmental Earth Science, 63, 1799-1822.

Iraqi Standards, (1989). IS No. 1387: 1989 Natural building stone. Baghdad, IS.

ISRM, International Society for Rock Mechanics, (1985). Suggested methods for determining point load strength. ISRM Suggested Method: Rock characterization testing and monitoring. Oxford: ISRM.

Jassim, H. M., Tokmachy, A. A. and Omar, H. M. (2015). Characterization of rock mass units along the abandoned Haibat-Sultan tunnel, Koya City, NE. Iraq. International Journal of Engineering Technology Management and Applied Sciences, 3 (3), pp. 129-140.

Jones, L. D. \& Jefferson,I.(2012). Expansive soils, Institution of Civil Engineers Manuals series, $46 \mathrm{p}$.

Karaman, S., Ersahin,S., \& Gunal, H. (2006). Firing temperature and firing time influence on mechanical and physical properties of clay bricks. Journal of Scientific and Industrial Research, 65, 153-159.

Khalid, A. A. (2012). Geotechnical assessment of soil from selected sites in Tikrit City Middle of Iraq. Tikrit Journal of Pure Science, 17 (3), 180-185.

Khanal, S. \& Tamrakar, N. K. (2009). Evaluation of quality of crushed limestone andsiltstone for road aggregates. Bulletin of Department of Geology, 12, 20-42.

Klein, C. (2002). The manual of mineral science, 22nd ed. New York: John Wiley \& Sons.

Krenz, J., Lee, B. D., Owens, P. R. (2006). Swelling clays and septic systems. Purdue Extension Bulletin $R W-3-W$.

Maala, K., Jabo, B., Al-Saad, N., Lafta, A., and Fayath, K., (2001). Assessment of quality and quantity of stratified clay soil for manufacture of clay brick in South of Mosul. Baghdad: Publication of GEOSURV.

Merza, T. A. (2004). The possibility of production of glazed ceramic tiles from the recent deposits, Sulaimani region, NE Iraq. Kurdistan Academic Journal, 3(1), 23-32.

Morales, D. M., Jahns, E., Ruedrich, J., Oyhantacabal, P., \& Siegesmund, S. (2007). The impact on partial water saturation in rock strength: an experimental study on sand stones. Zeitschrift der DeutschenGesellschaft fur Geowissenschaften, 158, 869882.

Naghoj, N. M., Yuossef, N. A. R., \& Maaitah, O. N. (2010). Mechanical properties of natural building stone: Jordanian building limestones as an example, Jordan Journal of Earth and Environmental Sciences, 3 (1), 37-48.

Nelson, J. D. \& Miller, D. J. (1992). Expansive soils: problems and practice in foundation and pavement engineering. New York: John Wiley \& Sons.

NZGS, New Zealand Geotechnical Society, (2005). Field description of soil and rock, New Zealand: Publication of NZ Geotechnical Society. 
Rasheed, Z. N., Ghafour, B. D., \& Omar, H. M. (2016). Assessment of shallow geotechnical properties, Koya City- North of Iraq. American Journal of Civil Engineering and Architecture, 4(2), 67-73.

Skempton, A.W. (1953). The colloidal activity of clays. Proceedings of 3rd International Conference of Soil Mechanics and Foundation Engineering, 1, 57-61.

Türkdönmez, O., Bozcu, M. (2012). The Geological, Petrographical and Engineering Properties of Rhyolitic Tuffs (Çan Stone) in Çan-E

tili Area (Çanakkale), NW Turkey: Their Usage as Building and Covering Stones, Open Journal of Geology, 2 (1), 25-33.

USCS, Unified Soil Classification System (1953). Technical Mémorandum No. 3-357, Office of the Chief of Engineers, Appendix A, Vol. 2; and Appendix B, Vol. 3. 